Ciencias

Veterinarias
Rev. Ciencias Veterinarias, Vol. 37, N³, [28], E-ISSN: 2215-4507

First Symposium on Regenerative Medicine and Nanotechnology, Costa Rica 2019 DOI: https://doi.org/10.15359/rcv.37-3.10

URL: http://www.revistas.una.ac.cr/index.php/veterinaria/index

\title{
3D polymeric scaffolds for oral tissue regeneration
}

\section{Andamios poliméricos 3D para regeneración de tejido oral}

\author{
Daniel Chavarría-Bolaños ${ }^{1}$, Diana Villalobos ${ }^{1}$, José Roberto Vega-Baudrit ${ }^{2}$ \\ 1 Facultad de Odontología, Universidad de Costa Rica. Email: danielchava2@gmail.com / diavive.28@gmail.com \\ 2 POLIUNA-CeNAT-CONARE, Costa Rica. E mail: jvegab@gmail.com
}

\begin{abstract}
A fundamental base of bioengineering and tissue regeneration is the selection and development of the scaffolds responsible for cell growth. However, finding the "ideal" scaffold depends not only on proposing an innovative idea, but also on considering multiple chemical, biological, and physical aspects that can be manipulated to optimize their future clinical performance. Multiple local variables (such as local inflammation, vascularity, tissue damage, immune response, among others), as well as systemic variables (diseases or concomitant treatments) can favor or affect the scaffold behavior in each case. The selection of the ideal scaffold for each case involves three indispensable steps: design, selection of manufacturing material, and visualization of the future biological function that each biomaterial will perform. The design is always a parallel process with the selection of the ideal biomaterial. Certain "light" scaffolds (such as membranes, hydrogels, or sponges) will require the use of polymers that allow their simple manipulation and early degradation, which in turn can favor the release of charged molecules previously included, obtaining an active scaffold known as drug delivery system. On the other hand, structural scaffolds that are prone to replace block compromised structures may need different designs and production techniques, where three-dimensional printing is included. All of these options should consider important aspects such as bioactivity, regenerative capacity, and biological response of the surrounding tissues. Some alternatives may induce greater cell adhesion and proliferation, while optimizing the osseointegration and healing processes. Other alternatives may play a more "active" role while promoting regeneration processes and controlling local infectious diseases or painful responses. In order to look for the best translational approach of the biomaterial, each option must be chosen with the correct diagnosis of the case to be treated.
\end{abstract}

\section{References}

Jafari M., Paknejad, Z., Rad, M.R., Motamedian, S.R., Eghbal, M.J., Nadjmi, N. \& Khojasteh, A. 2017. Polymeric scaffolds in tissue engineering: a literature review. J. Biomed. Mater. Res. B. Appl. Biomater. 105(2): 431-459. DOI: 10.1002/jbm.b.33547

Lu, Y., Aimetti, A.A., Langer, R. \& Gu, Z. 2016. Bioresponsive materials. Nat. Rev. 2(16075): 1-17. DOI: 10.1038/natrevmats.2016.75

Ou, K.L. \& Hosseinkhani, H. 2014. Development of 3D in Vitro Technology for Medical Applications. Int. J. Mol. Sci. 15(10): 17938-17962. DOI: 10.3390/ijms151017938 